PRZEGLĄD RUSYCYSTYCZNY 2020, nr 3(171)

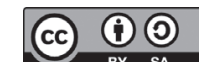

DOI $10.31261 /$ pr.7886

\author{
ANNA STRYJAKOWSKA \\ Uniwersytet im. Adama Mickiewicza w Poznaniu \\ (D ORCID: http://orcid.org/oooo-ooo1-9429-2849
}

\title{
POWIEŚĆ В СОВЕТСКОМ СОЮЗЕ НЕ БЫЛО АДДЕРОЛА OLGI BREININGER Z PERSPEKTYWY AUTOFIKCJI
}

\section{THE NOVEL В СОВЕТСКОМ СОЮЗЕ НЕ БЫЛО АДДЕРОЛА BY OLGA BREININGER FROM THE PERSPECTIVE OF AUTOFICTION} The aim of the article is to analyze Olga Breininger's novel as a field for constructing the author's identity. The category of autofiction, regarded as a tool of self-understanding and self-creation, has been chosen as the methodological foundation. The analysis of the literary text is embedded in the context of the author's non-literary activity, understood here not as biographical information, but as another (next to the fiction works) platform of self-creation. The interpretation of the novel focuses on the protagonist who experiences an identity crisis caused by chronic perfectionism and a sense of uprooting. Attention is given, among others, to the main character's memory operations, which play a key role in understanding her existential chaos. Creating the story as a generation's voice is considered as an important device, aimed at overcoming the feeling of loneliness.

Keywords: Olga Breininger, autofiction, self-creation, identity, perfectionism

Urodzona w 1987 roku w Karagandzie Olga Breininger uchodzi za jedną z najbardziej interesujących rosyjskich pisarek młodego pokolenia. Warto odnotować, że prowadzi ona również badania literaturoznawcze i działania popularyzujące literaturę, a także pracuje na rzecz aktywizacji młodych pisarzy. Istotny wpływ na twórczość Breininger ma jej wielopoziomowa tożsamość, związana przede wszystkim z licznymi zmianami miejsc zamieszkania. Pisarka spędziła dzieciństwo w Kazachstanie jako potomkini Niemców nadwołżańskich deportowanych do tego kraju w latach 40. XX wieku. Po ukończeniu Instytutu Literackiego im. Gorkiego w Moskwie przeprowadziła się do Niemiec, a potem do Oxfordu, gdzie ukończyła studia magisterskie. Stopień doktora 
uzyskała z kolei na Harvardzie na podstawie pracy o literackich obrazach Kaukazu Północnego. Doświadczenia te znalazły oddźwięk w debiutanckiej powieści В Советском Союзе не было аддерола, opublikowanej w periodyku „Дружба народов” w roku 2016, a rok później, wraz z kilkoma opowiadaniami, w formie samodzielnej książki. Sama pisarka zaprzecza co prawda, jakoby powieść miała charakter autobiograficzny, w moim przekonaniu można ją wszakże usytuować w kręgu autofikcji i analizować jako próbę samorozumienia oraz autokreacji.

Przed przystąpieniem do zasadniczej części rozważań zasadne wydaje się krótkie nakreślenie fabuły utworu, który jak dotąd nie doczekał się polskiego przekładu. Młoda bohaterka, której imienia ani nazwiska czytelnik nie poznaje, zostaje uczestniczką eksperymentu naukowego, kierowanego przez doktora Carlowa. Celem doświadczenia jest opracowanie współczesnej wersji nadczłowieka - jednostki, która dzięki doskonałej inteligencji i skuteczności będzie mogła kontrolować procesy zachodzące $\mathrm{w}$ świecie. Narzędziem naukowca jest system programowania neurokonfliktowego oparty na wykorzystaniu napięć generowanych przez heterogeniczne, często niekompatybilne doświadczenia życiowe. Bohaterka, urodzona w Związku Radzieckim doktorantka Harvardu, dzięki swoim nadzwyczajnym kompetencjom umysłowym i ambicji, a także poczuciu wykorzenienia, zawdzięczanemu wielokrotnej migracji, okazuje się idealną kandydatką na przyszłego nadczłowieka. Relacja protagonistki z bieżących wydarzeń jest przeplatana jej wspomnieniami z przeszłości, które uprawomocniają jej status obywatelki świata, zdolnej, ambitnej i silnej, choć zarazem wrażliwej młodej osoby. Czytelnik obserwuje jednocześnie równoległy proces fizycznego i psychicznego zmęczenia kobiety nieustannym perfekcjonizmem, sztucznie wspomaganym przez tytułową substancję $^{1}$. Wyczerpanie ujawnia się z całą mocą w trakcie trwania opisanego doświadczenia - bohaterka, choć jest wolontariuszką, obiera raczej rolę biernej obserwatorki, by w końcowej fazie projektu czynnie zagrozić jego powodzeniu. Zdolność do dojrzałej, pogłębionej autorefleksji pozwala kobiecie zakwestionować sens destrukcyjnych ambicji i udzielić głosu potrzebie zadumy, eksploracji własnych emocji i znalezienia psychicznej przystani.

W przypadku dzieła Breininger z pewnością nie mamy do czynienia z obecnością mocnego paktu autobiograficznego $\mathrm{w}$ rozumie-

${ }^{1}$ Adderall to oparty na solach amfetaminy lek na ADHD (zespół nadpobudliwości psychoruchowej z deficytem uwagi), stosowany również przez osoby niedotknięte tym zaburzeniem w celu poprawy koncentracji i wydolności umysłowej. 
niu Philippe'a Lejeune'a ${ }^{2}$ - nazwisko bohaterki nie jest określone, a autorka zawiera z czytelnikiem pakt powieściowy (wskazuje na to dopisek „Роман поколения”). W wywiadach pisarka dystansuje się również od kategorii „powieść autobiograficzna”. Jednocześnie na obecność postawy autobiograficznej (w ujęciu Małgorzaty Czermińskiej $^{3}$ ) wskazuje narracja pierwszoosobowa oraz potwierdzona przez samą autorkę zbieżność wielu elementów jej życiorysu z historią bohaterki.

W stosunku do intencjonalnie przedłożonych przez pisarkę informacji biograficznych warto wszelako zastosować zasadę ograniczonego zaufania i porzucić aspiracje dotarcia do obiektywnej prawdy o jej osobie. Bardziej zasadne wydaje się rozpatrywanie powieści w kluczu autofikcji w szerokim rozumieniu tego pojęcia. Według Serge’a Doubrovsky'ego, popularyzatora tej koncepcji, autofikcja polega na wpisaniu elementów z rzeczywistego życia w porządek powieści (języka)4 ${ }^{4}$. Doubrovsky uzupełnia zatem puste miejsce z teorii Lejeune'a: zapewnia o możliwości wprowadzenia bohatera o nazwisku tożsamym z nazwiskiem autora przy zachowaniu paktu powieściowego. Należy odnotować, że w odróżnieniu od autobiografii, spójnie odtwarzającej życie twórcy, autofikcja nastawiona jest na zachwianie twardymi podstawami Ja, stanowi, jak zauważa Anna Turczyn, fantazję o własnym pragnieniu, ustanawianie siebie $\mathrm{w}$ akcie pisania ${ }^{5}$. Obrazująca pęknięte Ja powieść Breininger wpisuje się w koncepcję autofikcji, nie zostaje jednak spełniony jeden warunek - tożsamość nazwisk autorki i narratorki-bohaterki (tej ostatniej, jak wspomniano, w ogóle nie nadano imienia). Rozwój teorii autofikcji, która wydaje się rozluźniać rygory definicyjne, pozwala wszelako zrezygnować z tożsamości nazwisk jako warunku sine qua non tej formy powieści. Wymóg zbieżności nazwisk kwestionuje na przykład Thierry Laurent, kładący nacisk na aspekt kreacji osobowości przy zachowaniu sprawdzalnych elementów autobiografizmu ${ }^{6}$. Jak konstatuje Jerzy Lis w monografii poświęconej współczesnemu pisarstwu autofikcyjnemu we Francji,

2 P. Lejeune, Paktautobiograficzny, tłum.A.W. Labuda, „Teksty” 1975, nr 5, s. 39-40.

3 M. Czermińska, Autobiograficzny trójkąt. Świadectwo, wyznanie i wyzwanie, Universitas, Kraków 2000, s. 120.

4 Zob. A. Turczyn, Autofikcja, czyli autobiografia psychopolifoniczna, „Teksty Drugie" 2007, Nr 1-2, s. 205.

5 Tamże, s. 206.

6 T. Laurent, L'œuvre de Patrick Modiano: une autofiction, Presses universitaires de Lyon, Lyon 1997, s. 11-12. Cyt. za: D. Cooke, Present Pasts: Patrick Modiano's (auto)biographical Fictions, Rodopi, Amsterdam-New York 2005, s. 80. 
pojęcie autofikcji jest przez literaturoznawców rozumiane wielorako ${ }^{7}$, w najnowszych zaś badaniach panuje tendencja do traktowania tego gatunku jako jednego z przejawów powieści autobiograficznej (a konkretnie - konfesyjnej) ${ }^{8}$. Kluczowa dla autofikcji będzie zatem fikcjonalizacja własnego doświadczenia, którą wolno ujmować zarówno jako próbę samorozumienia, jak i autokreacji - próbę najczęściej odsłaniającą niespójność, heterogeniczność, niepewność podmiotu. Powieść Breininger wpisuje się w taką wizję autofikcji.

W zakreślonym tu kontekście teoretycznym należy zaznaczyć, że moim celem nie jest ustalenie, które z elementów dzieła są zgodne z rzeczywistym życiorysem autorki. Poza identyfikacją kilku encyklopedycznych faktów tego typu tropienie śladów prawdy referencyjnej byłoby dla filologa zadaniem tyleż karkołomnym, co nieatrakcyjnym. Perspektywa autofikcji pozwala odejść od tego typu twardego biografizmu. Powieść В Советском Союзе не было аддерола traktuję jako jedno z pól autokreacji autorki, która świadomie buduje swój wizerunek współczesnej intelektualistki, pragnącej nadać profesji filologa odcień glamour (zgodnie z hasłem „Smart is the new sexy”, które Breininger zamieszcza w powieści, ale też aprobująco przytacza w jednym z wywiadów ${ }^{9}$ ); Breininger prowokuje również samo zainteresowanie własną osobą, mnożąc pytania o genezę jej sukcesu, a także o cenę, którą przychodzi jej za niego płacić. Możliwość odczytywania powieści jako autofikcji otwiera więc w dużej mierze zbieżność głównej bohaterki nie z jej rzeczywistą biografią, lecz z wizerunkiem autorki budowanym przez nią samą w mediach. Obok aktywności na łamie czasopism i portali literackich Breininger prowadzi profil w serwisie Instagram ${ }^{10}$, który, w mojej opinii, jest częścią autopromocji i istotną płaszczyzną popularyzacji jej działalności zarówno pisarskiej, jak i badawczej. Z profilu wyłania się obraz Breininger jako kobiety sukcesu - pisarki i naukowczyni ciągle rozwijającej swój warsztat, świetnie zorganizowanej obywatelki świata, współorganizatorki życia literackiego, profesjonalnej influencerki nastawionej na interakcję z obserwującymi. Tematy poddawane przez nią pod dyskusję odpowiadają kwestiom nurtującym

7 J. Lis, Obrzeża autobiografii. O wspótczesnym pisarstwie autofikcyjnym we Francji, Wydawnictwo Naukowe UAM, Poznań 2006, s. 56.

8 Tamże, s. 62-63.

9 Ольга Брейнингер: Smart is the new sexy, wywiad reide740, 2017, http://chitaem-vmeste.ru/zvyozdy/interviews/olga-brejninger-smart-is-the-new-sexy (25.04.2019).

${ }^{10}$ Profil „oliabreininger” w serwisie Instagram, https://www.instagram.com/oliabreininger/ (25.04.2019). 
bohaterkę powieści: Breininger otwarcie mówi o depresji, anoreksji i bezsenności, forsując przy tym tezę, że zaburzenia te można okiełznać i z powodzeniem prowadzić życie zawodowe; wiele miejsca poświęca tematyce samorozwoju, studiów na Harvardzie i zarządzaniu czasem; opisuje wreszcie swoje życie „na walizkach”, towarzyszące mu poczucie wykorzenienia i próby zbudowania alternatywnego domu - to właśnie wyzwanie zmierzenia się z poczuciem osamotnienia w wielkim świecie jest kluczowym tematem jej powieści, która wydaje się literackim dopełnieniem tak prowadzonej autokreacji.

Odczytanie dzieła jako autofikcji legitymizuje wreszcie sama autorka, która w wywiadach co prawda neguje autobiograficzność utworu, ale przyznaje jego performatywną funkcję w procesie konstruowania własnej tożsamości:

он очень личный и исповедального плана, с одной стороны, а с другой - очень придуманный и провокационный. Зачастую этот роман читают как автобиографический, и это сложно, учитывая, что там действительно очень много придуманного. Я страшно ценю, когда рецензент твердо дает понять, что не читает «Аддерол» как мою собственную историю. То, как написан роман, - это своего рода нарочитая обманка. Но работает немного и эффект сбывшегося пророчества - постепенно то, какой является моя героиня, просачивается в меня. Кажется, я потихоньку в нее превращаюсь ${ }^{11}$.

W przeważającej mierze wszakże możliwość czytania powieści В Советском Союзе не было аддерола jako autofikcji umocowana jest w intencji czytelnika. Ma on prawo odnieść się do deklaracji autorskich z dystansem, potraktować je jako element świadomie prowadzonej gry - gry, która może oddalać od prawdy referencyjnej, lecz w której wolno przecież dopatrywać się prawdy budowania wizerunku. Warto w tym miejscu zaznaczyć, że Breininger porusza się na ponowoczesnym gruncie rozmycia granic między prawdą a fikcją. Zapytana po raz kolejny o osobisty wymiar powieści, podkreśla:

Не могу сказать, что меня очень сильно занимает вопрос о „правильном” соотношении личного опыта и вымысла, автобиографии и художественного. Мне кажется, что все, что угодно, может стать основой для литературы - особенно сегодня, когда мы теряем грань между реальностью и виртуальным миром, когда правда перестала существовать, расщепившись на бесконечное количество версий реальности. В эпоху постправды вопрос о правде и вымысле, мне кажется, становится все менее и менее актуальным ${ }^{12}$.

${ }^{11}$ Ольга Брейнингер: Из Махачкалы увезу саблю и дружбу, wywiad R. Bakidowa, 2018, https://md-gazeta.ru/kultura/52307 (25.04.2019).

${ }^{12}$ Ольга Брейнингер: Smart... 
Po niezbędnych rozważaniach gatunkowych można przejść do analizy samej powieści. Ramowy wątek programowania nadczłowieka, jakkolwiek pretensjonalny by się wydawał, stanowi, po pierwsze, próbę nadania sensu egzystencji bohaterki, po drugie zaś - próbę scedowania odpowiedzialności za destrukcyjny perfekcjonizm na podmioty zewnętrzne. Motyw nadczłowieka to punkt, do którego zdają się wieść kolejne retrospekcje. Sięgając pamięcią do wyselekcjonowanych momentów z przeszłości, bohaterka dokonuje pewnej syntezy swojego życia, tworzy swego rodzaju mit o sobie jako jednostce inteligentnej, ambitnej i wydajnej, perfekcyjnie przystosowanej do życia we współczesnym świecie - przede wszystkim dzięki nabytej umiejętności nieprzywiązywania się do żadnych potencjalnych punktów oparcia:

Потому что нужно потерять абсолютно всё и даже надежду на это, потому что нужно перестать испытывать привязанность, любовь, тоску или страх. Потому что тебя уже ничего не испугает. Потому что ты сама отказалась от того, что могло быть, - из страха, что и это не сможет тебя согреть и заставить почувствовать себя дома ${ }^{13}$.

Poszczególnymi doświadczeniami, które prowadzą kobietę do stanu nadczłowieczeństwa, są: 1) emigracja do Niemiec i pobyt w obozie dla uchodźców, kiedy bohaterka wypracowuje sobie „drugą skórę" i poczucie sprawczości pomagające zapomnieć o panującym na świecie chaosie 2) studia w Oxfordzie, wywierające presję bycia najlepszą i propagujące myślenie merytokratyczne - przekonanie, że społeczny status człowieka jest wynikiem wyłącznie jego indywidualnych zdolności i pracy, w danym przypadku niewątpliwie wyniszczającej organizm; to również w Oxfordzie protagonistka opanowuje sztukę pozoru, a także uczy się pokonywać kryzys twórczy i fizyczne zmęczenie dzięki adderallowi, 3) wreszcie - zawiedziona miłość do Czeczena Amadiego, która wydaje się pozbawiać bohaterkę wszelkich pretensji do choćby drobnej stabilizacji, do odczuwania miłości i tęsknoty. Ten ostatni wątek budzi zresztą pewne wątpliwości. Po tym jak między dwojgiem ludzi zawiązuje się uczucie, Amadi znika bez słowa wyjaśnienia i po trzech miesiącach każe bohaterce odbyć samotną podróż po Bałkanach, by - jak się okazuje - emocjonalnie ją „zmiękczyć”

${ }^{13}$ О. Брейнингер, В Советском Союзе не было аддерола, АСТ, Москва 2017, wersja elektroniczna: https://www.litres.ru/olga-breyninger/v-sovetskom-souze-ne-bylo-adderola/ (12.06.2018). Wszystkie cytaty z powieści pochodzą ze wskazanego wydania. 
i przystosować do życia w konserwatywnym społeczeństwie kaukaskim. Rozważna dotąd i nastawiona na sukces kobieta tuż przed końcowymi egzaminami wyrusza w tę podróż, by zakończyć ją w Groznym jako narzeczona Czeczena, pozostawiona pod nadzorem kobiet z jego rodziny. Przyszłość protagonistki rysuje się w tym momencie radykalnie odmiennie niż jej dotychczasowy styl życia liberalnej, niezależnej intelektualistki. Opisane decyzje bohaterki wydają się na tyle niedorzeczne (i z góry skazane na porażkę), że wolno je interpretować jako poszukiwanie pretekstu do postawienia się w stan braku nadziei, zaprzestania (wymagających wszakże) poszukiwań punktu oparcia i zinternalizowania przypiętej przez otoczenie łatki burzycielki. Jak się okazuje, osiągnięcie tego stanu drogą naturalną nie jest możliwe, a tęsknota bohaterki za stałością nie ustaje nawet w ostatniej fazie eksperymentu. Kobieta nie jest w stanie w pełni kontrolować swoich emocji, kwestionuje swoje przystosowanie do świata permanentnej zmiany:

В мире, который можно перевозить в багаже и в котором отсутствуют любые ориентиры и привязки, единственное, что остается, чтобы не потеряться окончательно, - это придумать себе правила и отграничить ими территорию твоего мира от окружающего хаоса. Ведь хоть что-нибудь что-нибудь одно хотя бы! - должно оставаться неизменным, иначе теряется всякая вера и желание жить.

\footnotetext{
Что же поделать, если я не знаю, как удерживаться на земле, как пускать корни. Что же поделать, если я просто не могу остановиться.

Или могу?
}

Sytuacja bohaterki stanowi trafną ilustrację spostrzeżenia Zygmunta Baumana o tym, że w pełni ponowoczesny model tożsamości jest niezwykle trudny do spełnienia w obliczu właściwej większości ludzi potrzeby posiadania stałych punktów oparcia ${ }^{14} ;$ „[...] mamy postmodernizm, lecz rzadko spotykamy postmodernistów” - pisze z kolei Marek Szulakiewicz we wstępie do monografii Andrzeja Szahaja ${ }^{15}$. W świetle mącącego spokój przebudzenia humanistycznej autorefleksji bohaterki postać Carlowa można intepretować jako projekcję jej perfekcjonistycznych skłonności i energii destrukcji. O ile z operacji pamięci wyłania się obraz kobiety decyzyjnej, tytanki pracy,

${ }^{14}$ Z. Bauman, Ponowoczesne wzory osobowe, „Studia Socjologiczne” 2011, nr 1, S. 457-458.

${ }^{15}$ M. Szulakiewicz, Postmodernizm - pytanie o przyszłość, w: A. Szahaj, Postmodernizm w kulturze współczesnej, Wers, Bydgoszcz 2001, s. 8. 
upojonej myślą, że jej życie to przejrzysty wynik samodzielnie podjętych decyzji, o tyle w głównym planie czasowym bohaterka coraz bardziej odczuwa niszczycielski wpływ obranego stylu życia i myślenia. Pojawia się chęć scedowania odpowiedzialności za dokonane wybory na inną osobę albo na okoliczności zewnętrzne - rzekomo brutalne reguły gry współczesnego świata. Tymi słowami protagonistka oskarża w myślach naukowca:

Ты хотел разрушить остальной мир ради себя самого. Ты использовал боль, чтобы использовать людей. Ты хотел создать тысячу других, таких, как я, чтобы мы не боялись ничего, потому что нам нечего терять. Ты хотел направить нас против всего, что было нам дорого в той жизни, где существовали частицы смысла, и даже, если их было не так много, и даже, если они грозили вот-вот исчезнуть, испариться - простые человеческие привязанности и любовь удерживали их от распада.

Ты хотел создавать людей, которые бы были продуктом распада и живыми машинами с раскаленным добела интеллектом и ледяным разумом.

Oskarżenia te rozwija bohaterka w ostatnim rozdziale, w którym po roku od czasu eksperymentu przemawia na szczycie G20 w imieniu takich jak ona - młodych emigrantów, kosmopolitów, nastawionych na wiedzę i sukces, stanowiących zagrożenie dla globalnego porządku, który uczynił ich mentalnie bezdomnymi. Mówczyni obarcza społeczność międzynarodową winą za poczucie osamotnienia i wykorzenienia, za obojętność emocjonalną:

Я - ваша сирота. Мы - ваша ошибка. И если вы не знаете, сколько раз маленькой девочке нужно плакать навзрыд в самолете, чтобы постоянное чувство расставания и потери не стерлось и не стало привычным ноющим ощущением для молодой женщины, которая это все пишет сейчас, - это не моя проблема. Это ваша стратегическая ошибка.

Wymowny jest fakt, że poczucie rozgoryczenia przybiera wymiar kolektywny, choć próżno szukać w powieści bohaterów o podobnej sytuacji życiowej i poziomie akumulacji gniewu. Formułując pretensje wobec świata, protagonistka zawiesza jednak ogólnie egocentryczny ton narracji, jak gdyby poszukując sojuszników dla swego wołania o pomoc, jak gdyby pragnąc rozdzielić niesiony ciężar ambicji na większą liczbę osób. Owa nie do końca przejrzysta forma „my” może wskazywać na potrzebę przynależności, chęć przezwyciężenia doskwierającej samotności, umoszczenia się w cieple silnej zbiorowości. Jak zauważa Anna Turczyn, odwołując się do koncepcji Lacana i twórczości Doubrovsky'ego, w autofikcji dokonuje się rozpozna- 
nie przez podmiot własnego pragnienia; podmiot szuka tożsamości nie w tym, co mówi, lecz w samym sposobie mówienia, szczególnie w miejscach zaburzenia spójności dyskursu ${ }^{16}$. W formule „my” Olgi Breininger dostrzegam ślad tak ujmowanego pragnienia $-\mathrm{w}$ tym przypadku pragnienia wspólnoty, trwałej relacji z drugim człowiekiem, przezwyciężenia osamotnienia i pozwolenia samej sobie na emocje, przywiązanie i tęsknotę.

Zakończenie powieści jest otwarte i nie daje czytelnikowi jasnej odpowiedzi na pytanie o ostateczne powodzenie eksperymentu programowania nadczłowieka. Ucieczka, której dokonuje bohaterka w przedostatniej części utworu, może być kolejnym kontrolowanym kryzysem, wentylem bezpieczeństwa, który nie musi zagrażać doświadczeniu. Na szczycie G2o protagonistka przemawia już niepewna swojej tożsamości, niesiona destrukcyjnym zapałem, o który chodziło Carlowowi. Z drugiej strony, jak wynika choćby z cytowanych słów, uczucie bólu, straty i tęsknoty ciągle jej towarzyszy. Pasja przemowy wymyka się wizji cyborga, w którego miała przekształcić się kobieta. Owa granicząca z pretensjonalnością mglistość finału współtworzy mit o autorce - czytelnik ma prawo zastanawiać się, czy powieści bliżej jest do wołania o pomoc i sugestii, że w ten szaleńczy sposób na dłuższą metę żyć się nie da, czy może jest ona poświadczeniem statusu Breininger jako współczesnego nadczłowieka, któremu nadwątlone zdrowie wydaje się błahostką wobec osiągniętej pozycji i samozadowolenia. Powieść niewątpliwie spełniła zadanie gestu prowokacyjnego, wzbudziła dyskusję wokół osoby autorki. Jedną z nierozstrzygniętych zagadek jest w tym zakresie to, czy sukces Breininger jest wynikiem wspomagania tytułową substancją - nie chodzi tu wszakże o odpowiedź, lecz o samo postawienie rozpalającego odbiorców pytania. Pewne uspokajające w odniesieniu do poszukiwań stałości rozstrzygnięcie przynosi za to wypowiedź pisarki korespondująca z powieściowym pytaniem o dom. Bohaterka utworu brutalnie stwierdza: „- Дом, - говорю я себе зеркальной, - это то, что может быть у других, но никогда у тебя”. Breininger odpowiada w jednym z postów na Instagramie: „У меня нет «дома» в обычном понимании этого слова; мой дом - это дружбы, воспоминания и любовь, которые всегда остаются со мной, где бы я ни была" ${ }^{17}$.

${ }^{16}$ A. Turczyn, Autofikcja..., s. 209.

${ }_{17}$ О.Брейнингер, Пост-знакомство,https://www.instagram.com/p/Bv4HjiAH1Z1/ (25.04.2019). 


\section{ANNA STRYJAKOWSKA}

\section{REFERENCES}

Bauman, Zygmunt. “Ponowoczesne wzory osobowe.” Studia Socjologiczne 2011 no. 1. $435-458$.

Breyninger, Ol'ga. V Sovetskom Soyuze ne bylo adderola. Moskva: AST, 2017. [Брейнингер, Ольга. В Советском Союзе не было аддерола. Москва: АСТ, 2017].

Cooke, Dervila. Present Pasts: Patrick Modiano's (auto)biographical Fictions. Amsterdam-New York: Rodopi, 2005.

Czermińska, Małgorzata. Autobiograficzny trójkąt. Świadectwo, wyznanie i wyzwanie. Kraków: Universitas, 2000.

Laurent, Thierry. L'œuvre de Patrick Modiano: une autofiction. Lyon: Presses universitaires de Lyon, 1997.

Lejeune, Philippe. "Pakt autobiograficzny.” Transl. Labuda, Aleksander Wit. Teksty 1975 no. 5. 31-49.

"Ol'ga Breyninger: Iz Makhachkaly uvezu sablyu i druzhbu." 25 April 2019. <https:// md-gazeta.ru/kultura/52307> ["Ольга Брейнингер: Из Махачкалы увезу саблю и дружбу." 25.04.2019. <https://md-gazeta.ru/kultura/52307>].

"Ol'ga Breyninger: Smart is the new sexy." 25 April 2019. <http://chitaem-vmeste. ru/zvyozdy/interviews/olga-brejninger-smart-is-the-new-sexy> [“Ольга Брейнингер: Smart is the new sexy." 25.04.2019 <http://chitaem-vmeste.ru/zvyozdy/interviews/olga-brejninger-smart-is-the-new-sexy>].

Szulakiewicz, Marek. "Postmodernizm - pytanie o przyszłośc." Postmodernizm w kulturze współczesnej. Szahaj Andrzej, ed. Bydgoszcz: Wers, 2001.

Turczyn, Anna. "Autofikcja, czyli autobiografia psychopolifoniczna." Teksty Drugie 2007 no. 1-2. 204-211. 